\title{
Uji Aktivitas Antioksidan Ekstrak Etanol Daun Ganitri (Elaeocarpus Ganitrus Roxb.) dengan Metode DPPH (2,2 Difenil-1-Pikrilhidazi)
}

\section{Antioxidant Activity Test of Ganitri (Elaeocarpus Ganitrus Roxb.) Leaf Ethanol Extract Using the DPPH (2,2 Difenil-1-Pikrilhidazi) Method}

\author{
Naelaz Zukhruf Wakhidatul Kiromah*, Sadam Husein, Titi Pudji Rahayu \\ Program Studi Farmasi Program Sarjana, Sekolah Tinggi Ilmu Kesehatan Muhammadiyah Gombong, Jl. Yos \\ Sudarso No.461 Gombong, Kebumen 54412, Indonesia \\ *E-mail: naela.zukhruf18@stikesmuhgombong@ac.id
}

Received: 21 September 2020; Accepted: 27 Mei 2021; Published: 30 Juni 2021

\begin{abstract}
Abstrak
Radikal bebas merupakan salah satu penyebab terjadinya berbagai macam penyakit. Penggunaan senyawa antioksidan sintetis dapat mencegah radikal bebas namun menyebabkan efek buruk pada tubuh manusia seperti gangguan fungsi hati, paru-paru, usus, dan keracunan sehingga perlu dikembangkan antioksidan dari bahan alam. Tujuan penelitian ini adalah mengetahui aktivitas antioksidan ekstrak etanol daun ganitri (Elaeocarpus ganitrus Roxb.). Uji aktivitas antioksidan ekstrak etanol daun ganitri dilakukan menggunakan metode DPPH dengan pembanding vitamin C. Kemampuan antioksidan diukur berdasarkan penurunan absorbansi DPPH pada panjang gelombang $517 \mathrm{~nm}$ setelah penambahan ekstrak dengan konsentrasi 20, 40 ,80 dan 100 ppm. Hasil uji aktivitas antioksidan ekstrak etanol daun ganitri didapatkan persamaan regresi linier $\mathrm{y}=0.3779 \mathrm{x}+29.546$ dengan nilai $\mathrm{r}=0.4573$ dan diperoleh nilai $\mathrm{IC}_{50}$ sebesar 54,12 ppm. Ekstrak etanol daun ganitri (Elaeocarpus ganitrus Roxb) memiliki aktivitas antioksidan dengan kategori kuat.
\end{abstract}

Kata Kunci: Antioksidan, DPPH, Ganitri, $\mathrm{IC}_{50}$

\begin{abstract}
Free radicals are one of the cause of various diseases. The use of synthetic antioxidant compounds could prevent the effect of the free radicals, however may cause adverse effects on the human body such as impaired liver, lung, intestinal and poisoning. Therefore antioxidant from natural resources needs to be developed. The purpose of this research was to determine the antioxidant activity and $I_{50}$ value of the ethanol extract of ganitri (Elaeocarpus ganitrus Roxbs.) leaves. Ganitri leaf ethanol extract activity test was carried out using DPPH method with vitamin $C$ as a standard. Antioxidant activity was determined as a decreas in the absorbance of DPPH at $517 \mathrm{~nm}$ wavelength after an addition of the extract with the concentrations of 20,40,80, and $100 \mathrm{ppm}$. The antioxidant acitivity measurement of the ganitri leaf extract showed that the linier regression equation obtained was $y=0.3669 x+29.546, r=0.4573$ while the $I_{50}$ value was 54,12 ppm. Based on the result, it is concluded that the ethanol extract of ganitri (Elaeocarpus ganitrus Roxb.) leaf showed was categorized as strong antioxidant.
\end{abstract}

Keywords: Antioxidant, Ganitri, DPPH, $I C_{50}$

\section{PENDAHULUAN}

Kebiasaan hidup yang tidak baik mengakibatkan timbulnya penyakit seperti diabetes melitus, kanker, dan sebagainya. Salah satu penyebabnya yaitu radikal bebas. Radikal bebas adalah akumulasi elektron yang reaktif serta tak mempunyai pasangan dan dihasilkan oleh radiasi atau sebagai proses metabolisme. Radikal bebas dapat memicu timbulnya reaksi berantai yang menyebabkan disintegrasi membran sel (Divya et al, 2016). Radikal bebas akan menyerang sel-sel baik dalam tubuh sehingga menyebabkan hilangnya fungsi dan strukturnya (Liochev, 2013). Antioksidan merupakan setiap zat yang apabila dalam konsentrasi rendah dibandingkan substrat yang teroksidasi dapat secara signifikan menunda atau menghambat oksidasi substrat tertentu (Adriani \& Murtisiwi, 2020) . Tubuh 
memerlukan senyawa antioksidan yang dapat mencegah radikal bebas. Antioksidan sintetik mempunyai efek antioksidan yang sangat tinggi (Han et al, 2004), tetapi beberapa tahun belakangan ini telah dilaporkan bahwa penggunaan antioksidan sintetik dapat menyebabkan efek buruk pada tubuh manusia seperti gangguan fungsi hati, paruparu, usus, dan keracunan (Panagan, 2011).

Pengobatan alternatif menggunakan herbal telah banyak menarik perhatian masyarakat dan berkembang secara pesat. Tanaman yang digunakan sebagai pengobatan herbal sudah tersebar banyak hampir di seluruh wilayah Indonesia. Masyarakat menggunakan tanaman tersebut untuk mengatasi gangguan fisik dan mental. Indonesia memiliki beberapa tumbuhan yang digunakan sebagai pengobatan herbal salah satunya ganitri. Ganitri (Elaeocarpus ganitrus Roxb.) yaitu salah satu tumbuhan yang mempunyai efek sebagai antioksidan (Salampe et al., 2019).

Ganitri (Elaeocarpus ganitrus Roxb.) memiliki aktivitas Imunostimulan, antiinflamasi, animikroba, antijamur, antidepresan dan antioksidan (Kumar et al, 2011). Daun ganitri mengandung alkaloid, steroid, flavonoid, fenol, tanin, saponin dan terpenoid (Srikanth et al, 2018). Berdasarkan penelitian Kumar (2018) menyatakan bahwa flavonoid dan fenol yang terkandung di dalam daun ganitri memiliki aktivitas antioksidan (Singh and Kumar, 2018).

Selain itu pada penelitian Kumar (2014) menunjukan bahwa $85 \%$ kapasitas antioksidan tanaman ganitri adalah karena kontribusi dari fenolik dan flavonoid (Kumar and Thayumanavan, 2014). Penelitian tentang aktivitas antioksidan daun ganitri di Indonesia belum dilakukan. sehingga perlu dilakukan penelitian untuk mengetahui aktivitas antioksidan dari ekstrak etanol $70 \%$ daun ganitri dengan metode DPPH.

\section{METODE PENELITIAN}

\section{Alat dan Bahan}

Alat yang akan digunakan pada penelitian ini adalah Blender (Philips), penggaris, pensil, almunium foil, Timbangan analitik (AND GH-202), kertas saring, batang pengaduk, corong (Pyrex), labu ukur (Pyrex) tabung reaksi (Pyrex), plat KLT silika gel GF254 (Merck), pipa kapiler (Camag), Orbital shaker (Butchi), Chamber (Camag), Beaker glass (Pyrex), spektrofotometer vis (AMTAST AMV01), Vacuum rotary evaporator (EYELA N1000), alat semprot dan alat gelas lainya.

Bahan yang digunakan dalam penelitian ini adalah Daun Ganitri (Elaeocarpus ganitrus Roxb.) Vitamin C, Etanol 70\%, Akuades, DPPH, $\mathrm{FeCl}_{3}, \mathrm{HCl}$, dan serbuk magnesium.

\section{Determinasi Tanaman}

Daun Ganitri dideterminasi untuk mengetahui identitas dari tanaman. Determinasi dilaksanakan di Laboratorium Sistematika dan Tumbuhan Fakultas Biologi Universitas Gajah Mada Yogyakarta.

\section{Ekstraksi Daun Ganitri (Elaeocarpus ganitrus Roxb.)}

Sampel daun ganitri diperoleh dari Kabupaten Kebumen, Jawa Tengah. Daun ganitri disortasi basah, kemudian daun ganitri dirajang dan dikeringkan. Selanjutnya daun ganitri yang sudah kering disortasi kering dan dihaluskan sampai diperoleh serbuk simplisia kemudian serbuk simplisia kering diekstraksi maserasi dengan pelarut etanol $70 \%$. Sebanyak 5 gram serbuk simplisia dilarutkan menggunakan etanol $70 \%$ sebanyak $50 \mathrm{~mL}$ dan disimpan dalam orbital shaker selama \pm 24 jam. Ekstrak yang didapatkan disaring menggunakan kertas Whatman No.1 hingga diperoleh filtrat. Setelah itu ekstrak diletakkan di rotary evaporator dengan suhu $50^{\circ} \mathrm{C}$ untuk mendapatkan ekstrak kental (Kumar and Thayumanavan, 2014).

\section{Skrining Fitokimia}

Skrining fitokimia yang dilakukan dalam penelitian ini meliputi uji identifikasi senyawa fenol, dan flavonoid (Agustina and Handayani, 2017). 
5. Kromatografi Lapis Tipis Ekstrak Etanol Daun Ganitri (Elaeocarpus ganitrus Roxb.)

Pemeriksaan senyawa ekstrak daun ganitri (Elaeocarpus ganitrus Roxb.) dengan metode kromatografi lapis tipis (KLT) menggunakan plat silika gel $\mathrm{GF}_{254}$ yang sebelumnya diaktifkan menggunakan oven pada suhu $100^{\circ} \mathrm{C}$. Eluen yang digunakan berupa n-buthanol : asam asetat glasial : akuades (6:2:2). Ekstrak dielusi dengan kuersetin sebagai pembanding senyawa flavonoid. Kromatogram disemprot menggunakan penampak bercak $\mathrm{FeCl}_{3}$ untuk mengidentifikasi senyawa fenol dalam ekstrak. Hasil KLT di amati dibawah sinar tampak, sinar UV 254 dan $365 \mathrm{~nm}$.

\section{Uji Aktivitas Antioksidan dengan Metode DPPH}

\section{Pembuatan Larutan DPPH}

DPPH diambil 7,88 $\mathrm{mg}$ dilarutkan dalam etanol sebanyak $50 \mathrm{~mL}$ untuk mendapatkan larutan DPPH dengan konsentrasi $0,4 \quad \mathrm{mM}$. Larutan DPPH didiamkan dalam suhu rendah dan terlindung dari cahaya (Najihudin et al, 2017).

\section{Penentuan Panjang Gelombang \\ Maksimum}

Larutan DPPH ditimbang $1 \mathrm{~mL}$ diencerkan dengan etanol sampai dengan 5 $\mathrm{mL}$, kemudian disimpan selama 30 menit, kemudian diukur panjang gelombangnya pada 500-600 nm untuk mendapatkan absorbansi (Najihudin et al, 2017).

\section{Penentuan Operating Time larutan DPPH}

Penentuan Operating Time dilakukan dengan mereaksikan $50 \mu \mathrm{g} / \mathrm{ml}$ larutan pembanding vitamin $\mathrm{C}$ ditambah $4 \mathrm{ml}$ larutan DPPH, dicampur menggunakan stirer selama 1 menit dan ukur absorbansinya pada menit ke 5, 10, 15, 20, 25, dan 30 pada panjang gelombang maksimal yang sudah diperoleh (Nugraheni, 2007).

\section{Pengukuran Serapan Larutan Blanko}

Larutan DPPH diambil $1 \mathrm{~mL}$ dan ditambah etanol sebanyak $4 \mathrm{~mL}$ kedalam labu ukur, selanjutnya dicampur hingga sempurna dan disimpan selama 30 menit kemudian diukur serapan menggunakan sperktrofotometri UV-Vis pada panjang gelombang 500-600 nm hingga didapatkan panjang gelombang maksimum (Salampe et al., 2019).

\section{Pembuatan Larutan Standar Vitamin C Metode DPPH.}

Larutan stok 1000 ppm dibuat dengan melarutkan $50 \mathrm{mg}$ vitamin $\mathrm{C}$ dengan akuades sebanyak $50 \mathrm{~mL}$ hingga larut sempurna. Selanjutnya dipipet masing-masing sebanyak $100,200,300,400$ dan $500 \mu \mathrm{L}$ dan dicukupkan volumenya hingga $5 \mathrm{ml}$, sehingga diperoleh konsentrasi 2, 4, 6, 8 dan 10 ppm (Salampe et al., 2019).

\section{Pengujian Aktivitas Antioksidan Vitamin} C dengan DPPH.

Uji dilakukan dengan memipet $4 \mathrm{~mL}$ dari berbagai konsetrasi larutan vitamin $\mathrm{C}(2$, 4, 6 8, dan 10 ppm), kemudian ditambahkan dengan $1 \mathrm{~mL}$ DPPH hingga tercampur sempurna. Campuran disimpan 30 menit di ruang gelap, kemudian diukur absorbansi menggunakan spektrofotometri UV-Vis pada panjang gelombang maksimum (Salampe et al., 2019).

\section{Pembuatan Larutan Stok Ekstrak Daun Ganitri Metode DPPH.}

Larutan stok 1000 ppm dibuat dengan melarutkan $50 \mathrm{mg}$ ekstrak daun ganitri dengan etanol p.a sampai $50 \mathrm{~mL}$ dalam erlenmeyer hingga larut sempurna. Masingmasing dipipet sebanyak 100, 200, 300, 400 dan $500 \mu \mathrm{L}$ dan dicukupkan volumenya hingga $5 \mathrm{~mL}$, sehingga didapatkan konsentrasi 20, 40, 60, 80 dan 100 ppm (Salampe et al., 2019).

\section{Pengukuran Aktivitas Antioksidan Daun Ganitri Dengan DPPH.}

Ekstrak etanol daun ganitri (20, 40, 60, 80 dan 100 ppm) sebanyak $4 \mathrm{~mL}$ ditambah 1 $\mathrm{mL}$ larutan DPPH dicampur hingga larut sempurna, disimpan selama 30 menit, kemudian serapannya diukur dengan spektrofotometer UV-Vis pada panjang gelombang maksimum (Salampe et al., 2019). Masing-masing konsentrasi dilakukan 3 kali percobaan. 


\section{Analisa Data}

\section{Penentuan Persen Inhibisi}

Aktivitas antioksidan dinyatakan dengan persen inhibisi dengan menggunakan rumus (Hasanah et al., 2017):

$$
\text { Ob inhibisi }=\frac{\text { absorbansi blanko }- \text { absorbansi sampel }}{\text { absorbansiblanko }} \times 100
$$

\section{Penentuan $\mathrm{IC}_{50}$}

Nilai $\mathrm{IC}_{50}$ diperoleh dengan menghitung konsentrasi yang dibutuhkan untuk menghambat radikal bebas sebesar 50 berdasarkan persamaan garis regresi linier menggunakan rumus:

$\mathrm{y}=\mathrm{ax}+\mathrm{b}$

Keterangan:

$\mathrm{y}=50$

$\mathrm{x}=$ Konsentrasi larutan uji

\section{HASIL DAN PEMBAHASAN}

Ekstraksi dilakukan dengan pelarut etanol $70 \%$ menggunakan metode maserasi. Pemilihan etanol $70 \%$ karena pelarut polar yang dapat menarik senyawa polar juga seperti fenol (Dianasari \& Firdiyansari, 2019). Alasan pemilihan metode ini karena metodenya yang sederhana, murah dan tidak menggunakan pemanasan sehingga dapat meminimalisir kerusakan pada senyawa yang tidak tahan pemanasan. Rendemen ekstrak etanol daun ganitri sebesar $25,79 \%$.

Skrining fitokimia dilakukan dengan uji tabung dan kromatografi lapis tipis yang bertujuan untuk mengetahui kandungan senyawa dari ekstrak etanol daun ganitri. Hasil skrining fitokimia uji tabung dapat dilihat pada tabel 1. Ekstrak etanol daun ganitri memiliki kandungan senyawa yang berfungsi sebagai aktivitas antioksidan yaitu flavonoid dan fenol. Uji KLT dilakukan untuk mengidentifikasi kandungan senyawa aktivitas antioksidan pada daun ganitri.

Metode KLT dilakukan menggunakan plat silika gel $\mathrm{GF}_{254}$ yang sebelumnya dipanaskan menggunakan oven pada suhu $100^{\circ} \mathrm{C}$. Eluen yang digunakan berupa $n$ buthanol:asam asetat glasial:akuades dengan perbandingan 6:2:2, sedangkan senyawa pembanding yang digunakan adalah kuersetin. Senyawa kuersetin digunakan sebagai senyawa pembanding dikarenakan kandungan flavonoid yang terdapat pada ekstrak etanol daun ganitri tergolong dalam flavonoid jenis kuersetin (Dubey, 2018).

Tabel 1. Skrining fitokimia ekstrak daun ganitri (Elaeocarpus ganitrus Roxb.)

\begin{tabular}{lcl}
\hline \multicolumn{1}{c}{ Uji fitokimia } & Hasil uji & Keterangan \\
\hline Flavonoid & + & Terbentuk warna orange \\
\hline Fenol & + & Terbentuk warna hijau kehitaman \\
\hline
\end{tabular}

Hasil KLT dapat dilihat pada tabel 2. Ekstrak yang memiliki potensi sebagai aktivitas antioksidan dilihat berupa bercak kuning pada plat KLT dengan latar belakang ungu.
Berdasarkan hasil uji KLT diketahui bahwa ekstrak etanol daun ganitri positif mengandung flavonoid sebagai senyawa antioksidan.

Tabel 2. Tabel hasil perhitungan nilai Rf pada kromatogram

\begin{tabular}{lcccc}
\hline \multirow{2}{*}{ Sampel } & Rf & \multicolumn{3}{c}{ Pengamatan } \\
\cline { 3 - 5 } & & Sinar Tampak & Sinar UV 254 nm & Sinar UV 366 nm \\
\hline A. Kuersetin & 0.95 & Kuning & Hitam & Jingga \\
\hline C. Ekstrak Etanol & 0.98 & Kuning & Hitam & Jingga \\
\hline
\end{tabular}

Uji aktivitas antioksidan ekstrak etanol daun ganitri dilakukan menggunakan metode DPPH. Kelebihan dari DPPH yaitu metodenya yang sederhana, cepat, bahan yang digunakan sedikit serta peka untuk mengevaluasi senyawa dari bahan alam. 
Radikal DPPH sering digunakan karena memiliki stabilitas yang tinggi dan dapat diaplikasikan untuk senyawa lipofilik maupun hidrofilik (Irianti et al., 2015). Flavonoid sebagai senyawa antioksidan pada ekstrak etanol daun ganitri memiliki sifat mudah larut dalam air (hidrofilik), begitu juga vitamin $\mathrm{C}$ sebagai pembanding pada uji antioksidan dalam penelitian ini (Kementerian Kesehatan RI, 2014; Arifin and Ibrahim, 2018).

Hasil uji aktivitas antioksidan dari vitamin $\mathrm{C}$ sebagai pembanding dapat dilihat pada tabel 3 dan gambar 2 yang menunjukkan bahwa kurva regresi linier yang tidak lazim (kurva menurun), sedangkan pada uji aktivitas antioksidan ekstrak etanol daun ganitri didapatkan kurva regresi linier yang normal (kurva naik) gambar 3. Hasil nilai $\mathrm{IC}_{50}$ pada larutan pembanding yaitu vitamin $\mathrm{C}$ menunjukkan bahwa vitamin $\mathrm{C}$ memiliki aktivitas antioksidan yang sangat kuat seperti pada tabel 3. Pengukuran vitamin $\mathrm{C}$ pada setiap konsentrasi dilakukan 3 kali pembacaan pada spektrofotometri UV-Vis.

Tabel 3. Hasil uji antioksidan vitamin $\mathrm{C}$

\begin{tabular}{|c|c|c|c|c|c|c|}
\hline \multirow{2}{*}{$\begin{array}{l}\text { Konsentrasi } \\
\text { (ppm) }\end{array}$} & \multicolumn{3}{|c|}{ Percobaan } & \multirow{2}{*}{$\begin{array}{l}\text { Absorbansi } \\
\text { rata-rata }\end{array}$} & \multirow{2}{*}{$\%$ Inhibisi } & \multirow{2}{*}{$\mathrm{IC}_{50}$} \\
\hline & 1 & 2 & 3 & & & \\
\hline 2 & 0.192 & 0.192 & 0.192 & 0.192 & 67.29 & \multirow{5}{*}{5.42} \\
\hline 4 & 0.283 & 0.281 & 0.28 & 0.281 & 52.07 & \\
\hline 6 & 0.226 & 0.225 & 0.226 & 0.226 & 61.56 & \\
\hline 8 & 0.44 & 0.44 & 0.437 & 0.439 & 25.21 & \\
\hline 10 & 0.414 & 0.42 & 0.418 & 0.417 & 28.90 & \\
\hline
\end{tabular}

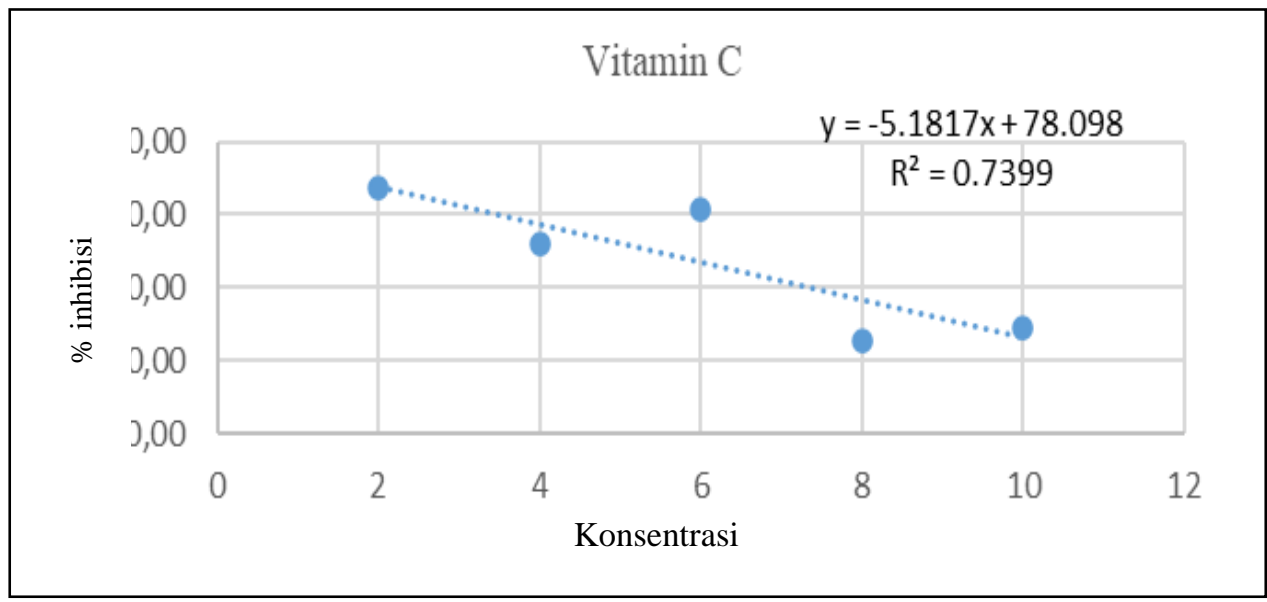

Gambar 2. Regresi linier vitamin C

Nilai IC $_{50}$ pada uji antioksidan dapat diklasifikasi menjadi bebebrapa tingkatan yaitu $\mathrm{IC}_{50}<50 \mu \mathrm{g} / \mathrm{mL}$ sangat kuat, $\mathrm{IC}_{50} 50$ $100 \mu \mathrm{g} / \mathrm{mL}$ kuat, $\mathrm{IC}_{50} \quad 101-150 \mu \mathrm{g} / \mathrm{mL}$ sedang, IC I0 $_{50} 151-200 \mu \mathrm{g} / \mathrm{mL}$ lemah, IC $_{50}>$ $200 \mu \mathrm{g} / \mathrm{mL}$ tidak aktif. Hasil uji aktivitas antioksidan ekstrak etanol daun ganitri seperti pada tabel 4 dan gambar 3 menunjukkan bahwa ekstrak etanol daun ganitri memiliki aktivitas antioksidan yang kuat dengan nilai $\mathrm{IC}_{50}$ sebesar 54,12 ppm. Senyawa yang terdapat dalam ekstrak daun ganitri yaitu flavonoid dengan mekanisme flavonoid akan memberikan elektronnya pada radikal untuk menstabilkan radikal, sehingga semakin tinggi kandungan flavonoid dalam ekstrak maka aktivitas antioksidanya semakin kuat. Hasil pengujian aktivitas antioksidan ekstrak daun ganitri pada penelitian sebelumnya didapatkan nilai 
$\mathrm{IC}_{50} 100 \mu \mathrm{g} / \mathrm{mL}$ pada penelitian Srikanth (2019) dan $297,12 \mu \mathrm{g} / \mathrm{mL}$ pada penelitian Kumar dkk (2008) (Kumar and Thayumanavan, 2014; Srikanth et al., 2018). Perbedaan hasil uji aktivitas antioksidan pada penelitian ini kemungkinan dikarenakan perbedaan pelarut dan metodenya. Pada penelitian Srikanth (2019) pelarut yang digunakan yaitu metanol namun metode yang digunakan adalah DPPH dan dihasilkan nilai $\mathrm{IC}_{50} 100 \mu \mathrm{g} / \mathrm{mL}$ (kuat) sedangkan pada penelitan Kumar (2008) pelarut yang digunakan adalah etanol namun metode uji aktivitas antioksidan yang digunakan yaitu ABTS (2, 2-azinobis-(3- ethylbenzothiazoline-6-sulphonate) dengan nilai IC $_{50}$ yang didapatkan sebesar 297,12 $\mu \mathrm{g} / \mathrm{mL}$ (tidak aktif). Hasil $\mathrm{IC}_{50}$ metode ABTS memang lebih besar dibandingkan dengan metode DPPH pada penelitian ini namun nilai $\mathrm{R}$ square pada metode ABTS lebih tinggi dari penelitian ini yaitu 0,8413 . Hal ini berarti bahwa metode ABTS lebih mampu menjelaskan pengaruh variabel bebas yaitu konsentrasi ekstrak daun ganitri terhadap variabel terikatnya yaitu nilai $\mathrm{IC}_{50}$. Metode ABTS secara umum lebih bagus dibandingkan dengan DPPH untuk deteksi aktivitas antioksidan pada senyawa yang bersifat hidrofilik (Floegel et al., 2011)

Tabel 4. Hasil uji aktivitas antioksidan ekstrak etanol

\begin{tabular}{|c|c|c|c|c|c|c|}
\hline \multirow{2}{*}{$\begin{array}{l}\text { Konsentrasi } \\
(\mathrm{ppm})\end{array}$} & \multicolumn{3}{|c|}{ Percobaan } & \multirow{2}{*}{$\begin{array}{l}\text { Absorbansi } \\
\text { rata-rata }\end{array}$} & \multirow{2}{*}{$\%$ Inhibisi } & \multirow{2}{*}{$\mathrm{IC}_{50}$} \\
\hline & 1 & 2 & 3 & & & \\
\hline 20 & 0,33 & 0,33 & 0,328 & 0,329 & 43,90 & \multirow{5}{*}{54,12} \\
\hline 40 & 0,421 & 0,421 & 0,419 & 0,420 & 28,39 & \\
\hline 60 & 0,185 & 0,189 & 0,188 & 0,187 & 68,09 & \\
\hline 80 & 0,294 & 0,296 & 0,296 & 0,295 & 49,69 & \\
\hline 100 & 0,17 & 0,171 & 0,169 & 0,170 & 71,04 & \\
\hline
\end{tabular}

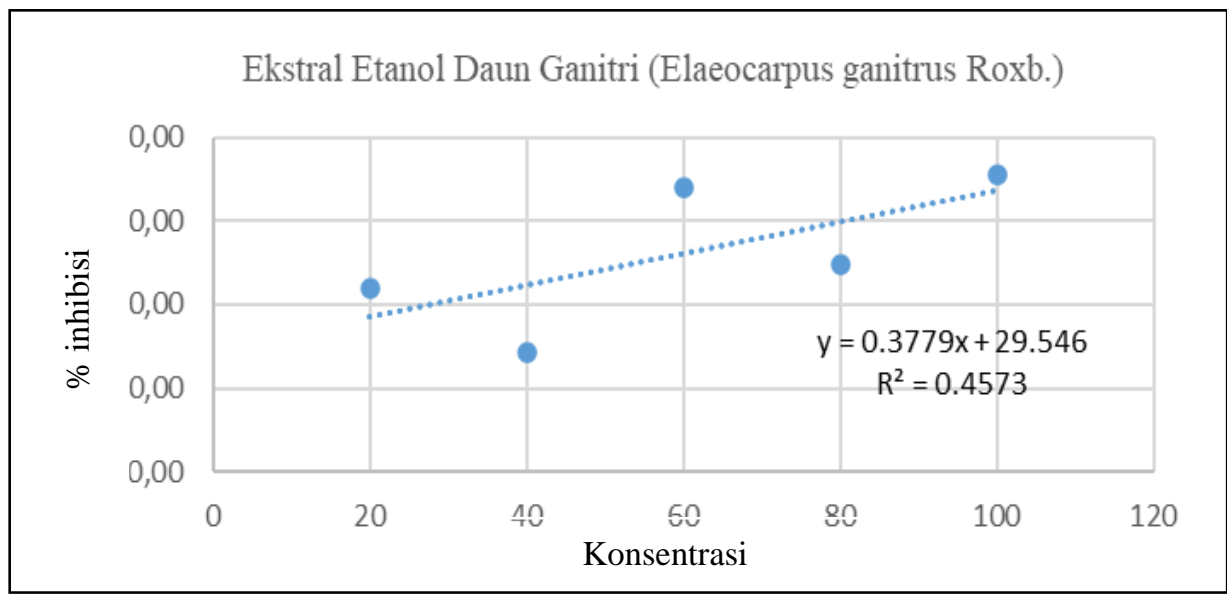

Gambar 3. Regresi linier ekstrak etanol

Berdasarkan hasil penelitian ini maka perlu dilakukan pengujian kembali aktivitas antioksidan ekstrak etanol daun ganitri menggunakan metode lainnya seperti ABTS. Nilai $r$ pada persamaan regersi linier ekstrak etanol daun ganitri sebesar 0,4573 dimana setiap seri konsentrasi dilakukan 3 kali percobaan.

\section{KESIMPULAN}

Berdasarkan hasil penelitian yang telah diperoleh pada penelitian ini, maka dapat disimpulkan bahwa ekstrak etanol daun ganitri (Elaeocarpus ganitrus Roxb.) memiliki aktivitas antioksidan dengan nilai $\mathrm{IC}_{50}$ sebesar 54,12 ppm. 


\section{Daftar Pustaka}

Adriani, D., \& Murtisiwi, L. 2020. Uji aktivitas antioksidan ekstrak etanol 70\% bunga telang (Clitoria ternatea L) dari daerah sleman dengan metode DPPH. Pharmacon: Jurnal Farmasi Indonesia, 17(1), 70-76.

Agustina, W. and Handayani, D. 2017. Skrining fitokimia dan Aktivitas antioksidan beberapa fraksi dari kulit batang jarak (Ricinus communis L.). Jurnal Pendidikan dan Ilmu Kimia, 1(2), pp. 117-122.

Arifin, B. and Ibrahim, S. 2018. Struktur, bioaktivitas dan antioksidan flavonoid. Jurnal Zarah, 6(1), pp. 21-29.

Dianasari, D., and Firdiyansari, I., 2019. Potensi ekstrak etanol herba apu-apu (Pistia stratiotes) dan fraksi-fraksinya sebagai antioksidan dengan metode DPPH. Pharmacon: Jurnal Farmasi Indonesia, 16(2), 83-88.

Divya, P.J., Jamuna, P., and Jyothi, L. A., 2016. Antioxidant properties of fresh and processes citrus aurantium fruit, Cogent Food \& Agriculture, 2(1).

Dubey, G. A. 2018. Effect of extract of rudraksa (Elaeocarpus ganitrus) on parkison's disease and depression. World Journal of Pharmaceutical Research, 7(12), pp. 937-947. doi: 10.20959/wjpr201812-12697.

Floegel, A., Kim, D.O., Chung, S.J., Koo, S.I., Chun, O.K. 2011. Comparison of ABTS / DPPH assays to measure antioxidant capacity in popular antioxidant rich us foods. Journal of Food Composition and Analysis, Elsevier Inc., 24(7), pp. 1043-1048. doi: 10.1016/j.jfca.2011.01.008.

Hasanah, M., Maharani, B., and Munarsih, E. 2017. Daya antioksidan ekstrak dan fraksi daun kopi robusta (Coffea robusta) terhadap pereaksi DPPH (2,2-difenil-1-pikrilhidrazil). Indonesian Journal of Pharmaceutical Science and Technology, 4(2).

Irianti, T., Puspitasari, A., Machwiyyah, L., Rabbani, H.R. 2015. Aktivitas penangkapan radikal 2-2 difenil-1-pikrilhidrazil (DPPH) ekstrak etanolik daun mengkudu (Morinda citrifolia L) dan batang brotowali (Tinospora crispa L.), fraksi air serta fraksi air terhidrolisis. Journal Traditional Medicine, 20(3), pp. 140-148.

Kementerian Kesehatan RI. 2014. Farmakope Indonesia. 5th ed. Jakarta: Direktorat Jendral Bina Kefarmasian dan Alat Kesehatan.

Kumar, G, Karthik, L., and Rao, K.V.B., 2011. Antimicrobial activity of Elaeocarpus ganitrus Roxb (Elaeocarpaceae ): an in vitro study. Bio Technologi, 40 (2011), pp. 5384-5387.

Kumar, T.S., and Thayumanavan, P., 2014. Evaluation of antioxidant properties of Elaeocarpus ganitrus Roxb leaves. Iranian Journal of Pharmaceutical Research. pp. 1-6.

Liochev, S.I., 2013. Reactive oxygen species and the free radical theory of aging. Free Radical Biology and Medicine, 60, pp 1-4.

Najihudin, A., Chaerunisaa, A. and Subarnas, A. 2017. Aktivitas antioksidan ekstrak dan fraksi kulit batang trengguli (Cassia fistula L) dengan metode DPPH. IJPST. 4(2).

Nugraheni. 2007. Perbandingan aktivitas antioksidan ekstrak etanol dan ekstrak metanol daun tempuyung (Sunchus arvensis L.) serta penentuan EC50 dengan metode DPPH (1,1difenil-2-pikrilhidrazil). Sekolah Tinggi Ilmu Farmasi Semarang, pp. 36-39.

Panagan, A. T. 2011. Isolasi mikroba penghasilan antibiotika dari tanah kampus UNSRI indralaya menggunakan media ekstrak tanah. Jurnal Penelitian Sains, 14(3).

Salampe, M., Rahma, Z., Nur, S., Mamada, S.S., 2019. Aktivitas antioksidan ekstrak etanol daun beroma (Cajanus cajan (L.) Milps ). Majalah Farmasi dan Farmakologi, 23(1), pp. 29-31. 
Singh, A. K. and Kumar, S. 2018. Comparison between compressive strength of rudraksha bead (Elaeocarpus ganitrus Roxb) in vertical and horizontal plane and bead properties. (6), pp. 38-44.

Srikanth, M. et al. 2018. Phytochemical screening and in vitro anti-oxidant activity of Elaeocarpus. Journal Pharmacy Science 1(1), pp. 2-4. 